\title{
Evaluation of the Efficacy of Computed Tomography Angiography in the Diagnosis of Brain Death
}

\section{Beyin Ölümü Tanısında Bilgisayarlı Tomografi Anjiografinin Etkinliğinin Değerlendirilmesi}

Isil Yurdaisik ${ }^{1}$,

${ }^{1}$ Istinye University Gaziosmanpasa Medical Park Hospital, Department of Radiology, Istanbul, Turkey

Gelis Tarihi/Received: 12 November 2018 Kabul Tarihi/Accepted: 03 January 2019

Address correspondence to: Isil Yurdaisik Istinye University Gaziosmanpasa Medical Park Hospital, Department of Radiology, Istanbul, Turkey

e-posta: mdisilyurdaisik@gmail.com

\section{ORCID}

Isil Yurdaisik

https://orcid.org/0000-0001-8316-1229

\begin{abstract}
Öz
Amaç: Beyin ölümü, beyin sapı dahil olmak üzere beynin bütün fonksiyonlarının tam ve geri dönüşsüz bi sekilde kaybı olarak tanımlanmaktadır. Beyin ölümü tanısında kullanılan üç esas bulgu koma, beyin sapı reflekslerinin yokluğu ve apnedir. Organ nakli bekleyen hastaların sayısındaki artış ile birlikte beyin ölümü tanısı daha da önemli bir hal almıştır. Bu çalışmada bilgisayarlı tomografi anjiyografinin (BTA) beyin ölümü tanısındaki etkinliğinin belirlenmesi amaçlanmıştır.

Hastalar ve Yöntem: Ekim 2015 ile Haziran 2018 arasında hastanemizin yoğun bakım ünitesinde yatan toplam 21 hastanın beyin ölümünün gerçekleştiği klinik olarak bildirilmiştir. Bu hastalardan birine manyetik rezonans anjiyografi (MRA) uygulandığı için çalışma dışı bırakılmıştır. Geriye kalan ve BTA sonuçlar mevcut olan toplam 20 hastanın bulguları retrospektif olarak yeniden değerlendirilmiştir. Hastaların yaşları 25 - 75 arasında değişmekte olup, ortalama yaş $45 \pm 1$ yıldır. BTA değerlendirmeleri 64 dedektör sıralı, döngü başına 128 kesit alan ve 384 kesite kadar yükseltilebilen bir cihaz ile yapılmıştır. $100 \mathrm{ml}$ kontrast madde, çift başlı bir otomatik pompa ile $350-375 \mathrm{mg} / \mathrm{ml}$ olacak şekilde $3.5-4 \mathrm{cc} / \mathrm{sn}$ hızında verilmiştir. Kontrast madde vermeye başladıktan sonra ilgili bölge (ROI) eşik değer olan 90-100 HU'ya ulaşınca aksiyel planda 15-20 sn aralığında tarama yapılmıştır. BTA bulguları 10 puanlı skala üzerinden değerlendirilmiştir.

Bulgular: Çalışmaya alınan ve BTA uygulanan 20 hastanın ölüm nedenleri olarak sekiz hastada intrakranial hemoraji, dört hastada iskemik serebrovasküler olay (SVO), üç hastada kraniotomi sonrası hemoraji, iki hastada kardiyak arrest, bir hastada travma sonrası kontüzyo serebri ve iki hastada metabolik nedenler olarak bildirilmiştir. Toplam 20 hastada ACA, PCA, MCA distal ve ICA supraklinoid dallarında kontrast dolumu "0" iken, 8 hastada ise MCA proksimal dallarında kontrast dolumu saptanmıştır. İki hastada tek tarafıı ACA proksimalinde şüpheli bir kontrast dolumu belirlenmiştir. Intrakraniyal dalların her birindeki opasifikasyon kaybına 1 puan verilmiştir. Buna göre 20 hastanın tümü toplam 10 puan almıştır. Sonuç: Organ nakilleri için yasalarla gerekliliği belirlenmiş beyin ölümü tanısı için BTA'nın etkin ve geçerli bir doğrulayıcı yöntem olduğunu düşünmekteyiz.
\end{abstract}

Anahtar Kelimeler: Bilgisayarlı tomografi anjiyografi, beyin ölümü, organ nakli, görüntüleme

\section{Abstract}

Aim: Brain death is defined as the complete and irreversible loss of all brain functions including the brain stem. Three major findings used for the diagnosis of brain death are coma, absence of brain stem reflexes and apnea. The diagnosis of brain death has become more important with the increasing number of patients waiting for transplantation. The objective of this study was to determine the efficacy of computed tomography angiography (CTA) in confirming brain death.

Patients and Methods: Clinical brain death was reported in total 21 patients hospitalized in the critical care unit of our hospital between October 2015 and June 2018. One of these patients was excluded since he underwent magnetic resonance angiography. CTA findings of the remaining patients were retrospectively evaluated. Patients were aged between 25 and 75 years with a mean age of $45 \pm 1$ years. CTA evaluations were performed using a 64 detector device. $100 \mathrm{~mL}$ contrast agent was delivered with a double head automated pump at a rate of $3.5-4 \mathrm{cc} / \mathrm{sec}$ as $350-375 \mathrm{mg} / \mathrm{mL}$. When the region of interest reached 90-100 HU cut off value, the images were acquired at 15-20 sec intervals on the axial plan. CTA findings were interpreted using 10 - point scale.

Results: Causes of death were reported as intracranial hemorrhage in eight patients, ischemic cerebrovascular events in four patients, hemorrhage after craniotomy in three patients, cardiac arrest in two patients, post-traumatic contusio cerebri in one patient, and metabolic reasons in two patients. Contrast filling was " 0 " in the ACA, PCA, MCA distal, and ICA supraclinoid branches of all 20 patients. Suspected contrast filling was found in MCA proximal in eight patients and unilateral ACA proximal in two patients. Each loss of opacification in the intracranial branches was scored as 1 point. Accordingly, al patients were scored as 10 points.

Conclusion: According to our results, CTA is an effective and sensitive method for the diagnosis of brain death which is obligated by regulations.

Keywords: Computed tomography angiography, brain death, organ transplantation, imaging

Cite this article as: Yurdaisik I. Evaluation of the Efficacy of Computed Tomography Angiography in the Diagnosis of Brain Death. Selcuk Med J 2019;35(4): 242-248
Disclosure: Author has not a financial interest in any of the products, devices, or drugs mentioned in this article. The research was not sponsored by an outside organization. Author has agreed to allow full access to the primary data and to allow the journal to review the data if requested. 


\section{INTRODUCTION}

Before the term of brain death has widely adopted worldwide, medical death has been defined as circulatory and respiratory arrest. Following the advancements in ventilation and cardiopulmonary fields, this definition has become different and the term of "Brain Death" has been introduced (1). Brain death is defined as complete and irreversible loss af all functions of the brain including the brain stem. A scientific committee from the Harvard Medical Faculty published a landmark document titled "Definition of Irreversible Coma." The first official definition of brain death was included in this document. A new definition, which focuses on the loss of neurologic function in addition to the traditional methods used for determination of medical death such as the loss of cardiorespiratory function was proposed (1). Making this definition was resulted from the need of identifying patients without cerebral functions despite persistent heart beats who receive mechanical ventilation in intensive care units, and not from the need for organ transplantation.

The clinical diagnosis of brain death is established according to legal regulations in many countries. With widely performed organ transplantations, the diagnosis of brain death has become more important. One of the most important problems encountered with organ transplantation in Turkey is inability to correctly and timely management of diagnosis process of brain death. In our country, the number of patients waiting for organ transplantation is rapidly increasing every passing day. According to the data from the Turkish Ministry of Health, approximately 25,000 patients are awaiting their turn for organ transplantation (2). On the other hand, patients with brain death who could become candidates for organ transplantation increase the load of intensive care unit, while no donor can be found for the patients waiting transplantation. The following three major findings should be detected in order to make a diagnosis of brain death: 1) coma state and nor response to stimuli, 2) complete loss of brain stem reflexes, and 3) apnea (3).

In order to make the decision for irreversible loss of brain functions: The cause of coma should be determined, medical conditions that may affect the results should be ruled out, and the patient should be supervised for a duration enough to make decision for irreversible coma (4).

Medical conditions that may affect the decision for irreversible brain death include hypothermia, the use of drugs suppressing central nervous system, injury of the upper cervical vertebrae, neuromuscular paralysis, severe acid-base electrolyte disorders and endocrine abnormalities (5).

When test results are not reliable or apnea test could not be performed, the process is continued with supportive tests. The aim of using imaging techniques in the diagnosis of brain death is to determine whether there is any cerebral electrical activity. Numerous blood flow test methods have been developed including cerebral angiography, CT/ $\mathrm{MRI}$ angiography, perfusion scintigraphy, transcranial Doppler sonography, perfusion CT, Xenon CT, MRI spectroscopy, diffusion weighted MRI and functional MRI.

Although today digital subtraction angiography technique (DSA) is used as the gold standard in the diagnosis of brain death, research on new alternative techniques is continuing, because DSA is an invasive method difficult to perform and cannot performed bedside. Computed tomography angiography (CTA), which is among these methods, was used for the first time by Dupas et al. (6) in the diagnosis of brain death in 1998. There are many studies in the literature about the advantages of CTA. However, there is no general consensus on applications and parameters of this technique in the diagnosis of brain death.

The objective of this study was to determine efficacy of computed tomography angiography (CTA) in the diagnosis of brain death by discussion its parameters in the light of the literature.

\section{PATIENTS AND METHODS}

A total of 21 patients who were admitted to the intensive care unit and whose brain death was clinically reported between October 2015 and June 2018 were retrospectively evaluated in this study. One of these patients was excluded from the study since magnetic resonance angiography (MRA) was performed. CTA results of the remaining 20 patients were evaluated again using 10-point scale criteria of CTA in the diagnosis of cerebral flow arrest. Electroencephalography (EEG) was not performed in any patient. Neurological brain stem reflex examination was carried out in all patients. Apnea test could not be performed in 5 patients due to low saturation. Of the 21 patients reported to organ transplantation Regional Coordination Center, only one patient attorney accepted preferential transplantation, and all of the other attorneys rejected transplantation. Intensive care process of the patients other than this patient with donor care was terminated. 
CTA evaluations were performed using Siemens Somatom device with 64 detectors and 128 sections per cycle that could be raised up to 384 sections. Multidetector CTA screenings were performed using the protocol described by Dupas et al. (6). The first screenings were carried out without contrast agent. Contrast agent of $100 \mathrm{~mL}$ was then delivered with a double headed automated pump at a rate of 3.5$4 \mathrm{cc} /$ seconds. When the region of interest (ROI) reached 90-100 $\mathrm{HU}$, which was the threshold value, after administration of contrast agent, screening was performed at axial plane for $15-20$ seconds and the series between and after the contrast enhancement were obtained.

\section{Evaluation of Cerebral Flow Arrest with CTA}

Although the brain constitutes only $2 \%$ of the body mass, it received a large part of cardiac output (12\% - 15\%) during resting in adults. Cerebral blood flood (CBF) is calculated by dividing cerebral perfusion pressure (CPP) by cerebrovascular resistance (CVR). Cerebral perfusion pressure is measured by the difference between mean arterial pressure (MAP) and intracranial pressure (ICP) values. In conclusion, the amount of cerebral blood flow is calculated according to the following Poiseuille formula:

$\mathrm{CBF}=\mathrm{CPP} / \mathrm{CVR}=(\mathrm{MAP}-\mathrm{ICP}) / \mathrm{CVR}$

In normal adults, CPP usually varies between 70-90 $\mathrm{mmHg}$. Whereas CBF is measured as $45-60 \mathrm{~mL} / 100$ $\mathrm{g}$ in normal cerebral tissue. Mass effect created by cerebral edema occurring in brain damage, leads to an increase in intracranial pressure. Damage occurring in the brain begins from the first trauma points and spreads to the entire brain. Although intracranial vessels are compressed, the arterial flow continues. Cerebrovascular resistance is protected by regulation mechanisms by decreasing vascular tonus. Blood flow in the brain vessels is restricted due to the increased ICP during cerebral damage. The absence of cerebral blood flow and perfusion is related to brain death. It is thought that increased intracranial pressure (ICP) is the most important pathophysiological mechanism, which lead to complete cessation of cerebral blood flow (7).

The earliest finding in determination of the absence of cerebral flow is the loss of opacification in the deep vessels, galen vein and internal cerebral veins. Although there was no widely accepted criterion in determination of the loss of opacification until recent years, studies have proposed three assessment systems: 10-point, 7-point, and 4-point scales. Among these scales, 10-point scale includes the loss of opacification in the intracranial vessels of the anterior and posterior cerebral circulation, while 7-point and 4-point scales involves only the anterior circulation. The common criterion of all scales in the diagnosis of brain death is the loss of opacification in the middle cerebral arteries (MCA - M4) and the cortical branches of deep cerebral veins. The arteries and veins examined in these three scales are shown in Table 1.

Statistical analysis of the data was performed with Fisher Exact test using SPSS version 20.

\section{RESULTS}

This study included 21 patients who were admitted to the intensive care unit between October 2015 and June 2018. Among these patients, one was excluded from the study because of being examined with magnetic angiography (MRA). The diagnosis of brain death was evaluated again with computed tomography angiography technique in the remaining 20 patients.

Of all patients, 10 (50\%) were male and 10 (50\%) were female. Patients aged between 25 and 75 years with a mean age of $45 \pm 1$. Causes of death of all patients are shown in Table 2 .

Contrast enhancement was found as " 0 " in supraclinoid branches of ACA, PCA, MCA distal and ICA in 20 patients, while contrast enhancement was found in the proximal MCA branches in 8 patients. Suspected contrast enhancement was found in unilateral ACA proximal in two patients. In the

Table 1. 10, 7, and 4-point scales used in the measurement of the loss of opacification

\begin{tabular}{ll}
\hline Criteria & Loss of Opacification \\
\hline 10 Point & BA \\
& Right and left PCA-P2 \\
& Right and left ACA-A3 \\
& (pericallosal artery) \\
& Right and left MCA-M4 \\
& Right and left ICV \\
& GCV \\
& Right and left ACA-A3 \\
& (pericallosal artery) \\
& Right and left MCA-M4 \\
& Right and left ICV \\
& GCV \\
& Right and left MCA-M4 \\
& Right and left ICV \\
& Point \\
BA: basilar artery; & PCA: posterior cerebral artery; ACA: anterior cerebral \\
artery; MCA: middle cerebral artery; ICV: internal cerebral vein; GCV: \\
great cerebral vein
\end{tabular}


Table 2. Reported causes of death in all patients

\begin{tabular}{lll}
\hline Cause of death & N & \% \\
\hline Intracranial hemorrhage & 8 & 40 \\
Ischemic cerebrovascular event & 4 & 20 \\
Hemorrhage after craniotomy & 3 & 15 \\
Cardiac arrest & 2 & 10 \\
Contusio cerebri after trauma & 1 & 5 \\
Metabolic causes & 2 & 10 \\
\hline
\end{tabular}

evaluation performed according to 10-point scale, 1 point was given for loss of each intracranial branches, and these losses in distal were illustrated in Figure 1 (8). Although losses of opacification in the anterior and posterior circulations at various levels have been reported in the reference publications, in our study suspected opacification was found MCA proximal branches in eight patients and in unilateral ACA in two patients. Distributions of non-opacification conditions according to the vascular structures with 10-point scale criteria are given in Table 3 .

Sensitivity of CTA in the diagnosis of brain death was found as $100 \%$ due to the loss of opacification in all vascular structures.

Computed tomography angiography samples of the patients included in our study are given in Figures 2, 3 and 4 .

\section{DISCUSSION}

In our country, no sufficient donors are found for organ transplant and the number of patients waiting for transplantation is rapidly increasing. Inability to timely making the diagnosis of brain death both increase load of intensive care units, and results in morbidity or mortality since donors are not found for the patients waiting transplantation. According to our legal regulations, after the clinical diagnosis of brain

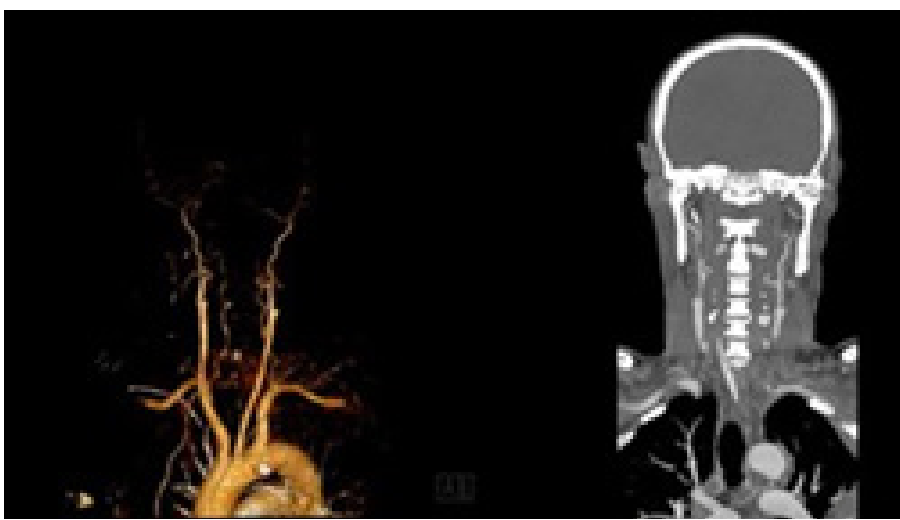

Figure 2. There is no internal carotid artery $8 \mathrm{ICA}$ ) flow from the bifurcation in volume render technique 8VRT) and coronal maximum intensity projection (MIP) images of a 75-yearold female patient. No dural penetration was observed in the vertebral arteries. External carotid artery (ECA) can be monitored up to the superficial temporal branches.

death, it is mandatory to confirm the brain death with confirmatory tests. Clinical and supportive tests are used for the diagnosis of brain death. Although DSA is accepted as the gold standard among the supportive tests, debate remains on this technique in the literature because of its disadvantages. DSA is an invasive and time consuming technique, requires experienced neuroradiologists and the number of cerebral angiography units is limited. Therefore, catheter angiography has been proposed to be replaced by newer techniques such as MRA and CTA. Studies on MRA are dated back to 2002, but recently CTA has drawn attention (9). CTA was used for the first time by Dupas et al. in the diagnosis of brain death in 1998 according to 10-, 7- and 4-point scales, and its sensitivity was reported as $100 \%$
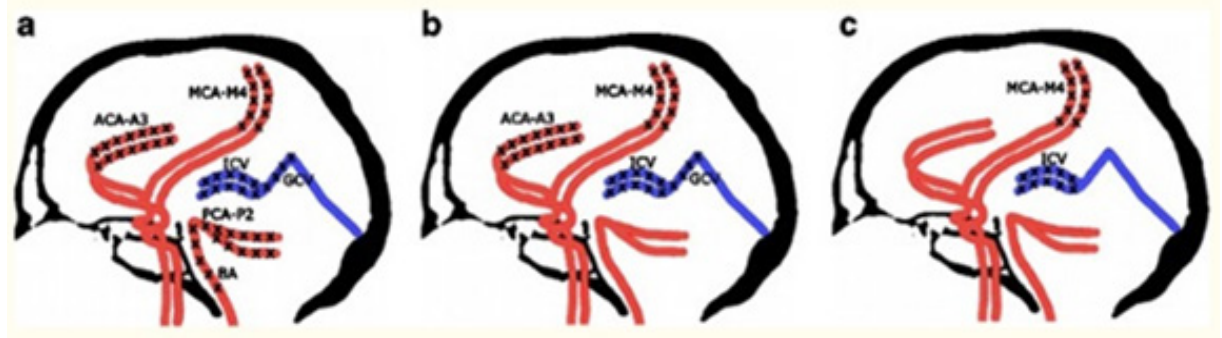

Figure 1. Loss of opacification of the vessels used in the scale for the diagnosis of brain death by CTA a) Positive outcome:10 points: Bilateral PCA-P2, BA, Bilateral ACA-A3, Bilateral MCA-M4, Bilateral ICV, GCV b) Positive outcome:7 points: Bilateral ACA-A3, Bilateral MCA-M4, Bilateral ICV, GCV c) Positive outcome:4 points: Bilateral MCA-M4, Bilateral ICV, GCV Negative outcome (no brain death occurred) between 0-3 Points 
Table 3. Loss of opacification conditions of the vascular structures on CTA

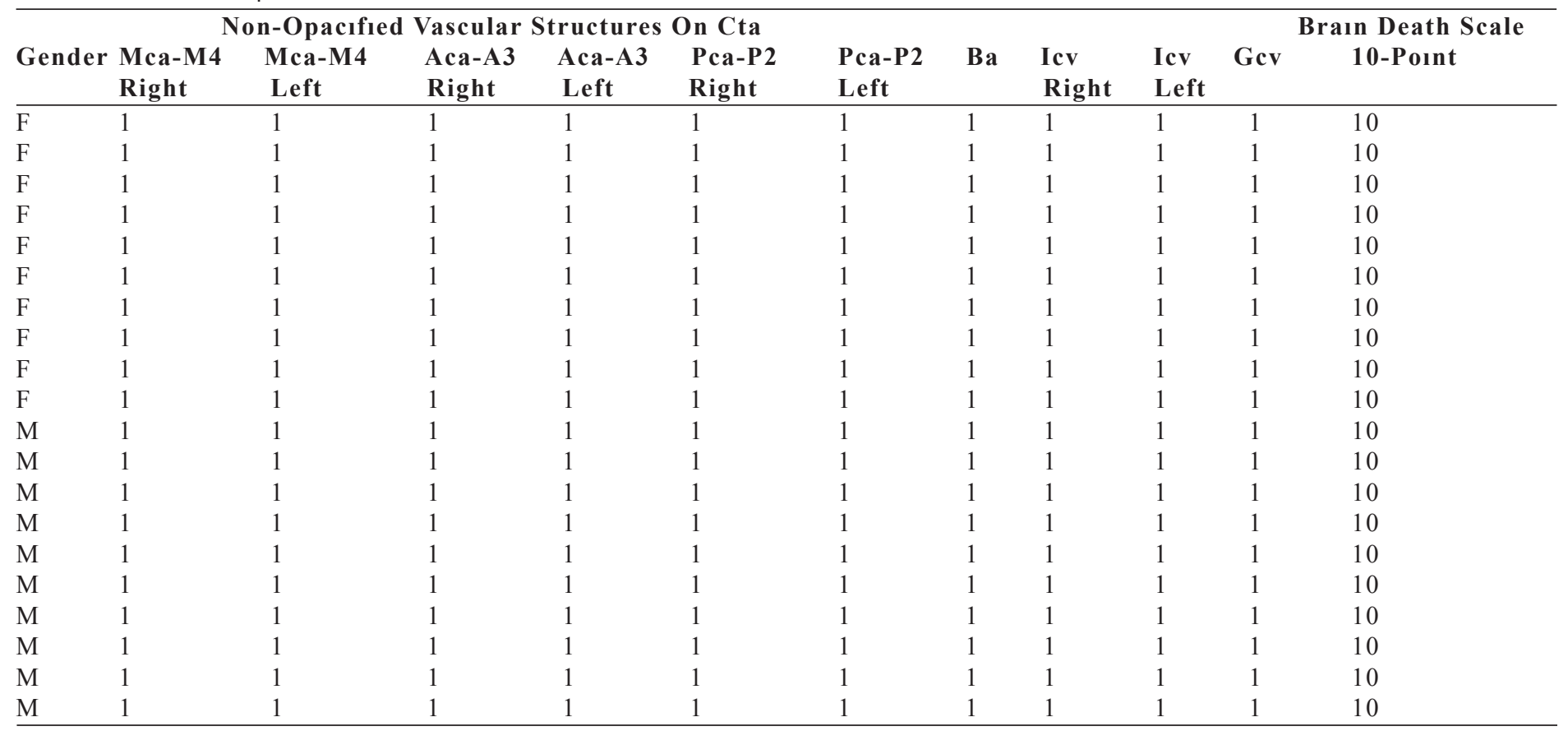

in a series of 14 patients (6). CTA was used as a confirmatory test in many studies since that time. In our study also we investigated whether CTA is a sufficient and valid confirmatory diagnostic method for the diagnosis of brain death, necessity of which has been determined by legal regulations, according to 10-point scale that has been also used in the previous studies. Sensitivity of CTA in the diagnosis

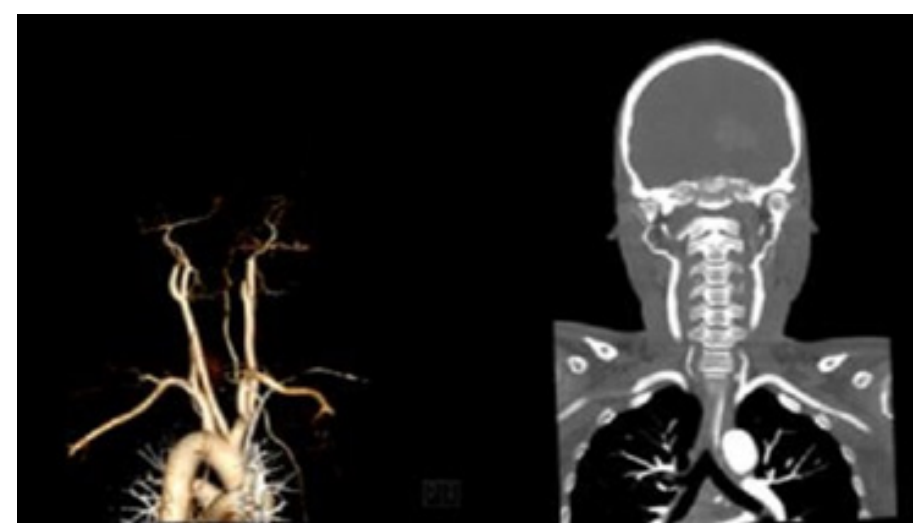

Figure 3. There was a passage until the right cervical segment in VRT (left) and coronal MIP (right) images of a 38-year-old female patient, while it remains at the level of carotid bulbus at the left. No dural penetration was observed in the vertebral arteries. of brain death has been reported by variable rates in the literature. When studies conducted on this subject in our country were evaluated; in a study by Şahin and Pekçevik in 2015, CTA results of 25 patients were re-evaluated and sensitivity values of this method in determination of brain death were found as $52 \%$, $64 \%$ and $88 \%$ according to $10-, 7$ - and 4 -point scales, respectively (10). In our study, CTA confirmed the clinical diagnosis of brain death in all patients with a

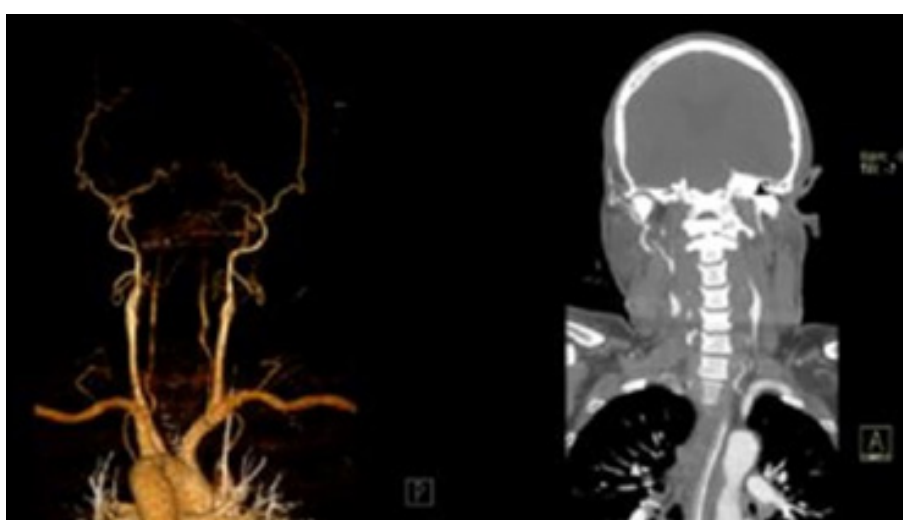

Figure 4. ICA was monitored until the level of carotid bulbus in VRT (left) and coronal MIP (right) images of a 55-year-old male patient. Occipital, superficial temporal and posterior auricular branches of ECA can be seen. 
sensitivity found as $100 \%$. Similar to our study, in a study by Karakuş et al. in 2014, CTA results of the 14 patients who were referred from intensive care unit with the clinical diagnosis of brain death were evaluated again according to 4-point scale (11). CTA findings were reported to be consistent with the clinical diagnosis inn all patients. In a multicenter prospective study by Sawicki et al. from Poland in 2014 with CTA, 82 patients were examined and the sensitivity was reported as $96 \%$ (12). In a multicenter study by Frampas et al. published in 2009, a total of 105 patients with clinical diagnosis of brain death in 6 center during 1 year were prospectively evaluated. In that study, sensitivity of CTA was reported as $86 \%$ and specificity as $100 \%$ in the diagnosis of brain death (13). In a study by Garret et al. from the USA published in 2018, CTA results of 18 patients were evaluated in terms of brain death (14). Sensitivity of CTA was reported as $75 \%$, specificity as $100 \%$, positive predictive value as $100 \%$ and negative predictive value as $33 \%$. The authors concluded that statistical performance of CTA was comparable with many confirmatory tests. In a meta-analysis by Brasil et al. in 2015, results of 122 studies including 322 patients and evaluating the use of CTA for the diagnosis of brain death were reviewed (15). The mean sensitivity of CTA was reported as $87.5 \%$. The authors reported that CTA showed a high sensitivity for the patients previously diagnosed with brain death according to clinical criteria, and that current evidence supporting the use of CTA was comparable with the other methods used worldwide. In a study by Combes et al. with 43 patients, sensitivity of CTA in confirmation of brain death was reported as $70 \%$ (16). In the studies except the study by Combes et al., a part of intracerebral branches of ICA could be seen, while in our study proximal segments of the intracerebral branches could be observed in some patients. This was thought to be resulted from the insufficient compensatory mechanism caused by prolonged order and application durations of CTA since those patients were not in emergency category.

Opinions about the use of CTA as a confirmatory test for the diagnosis of brain death vary among different studies in parallel with the variability of CTA sensitivity in the literature. In a Cochrane study by Taylor et al. in 2014, large case series and cohort studies evaluating the use of CTA in the confirmation of the diagnosis of brain death were assessed. In that study, it was reported that CTA results of 366 patients did not support the use of CTA as a mandatory test in the management of patients with suspected brain death or replace it with neurologic evaluations (17). In a study by Berenguer et al. comparing the results of computed tomography angiography and nuclear medicine perfusion screening, it was reported that the use of CTA for confirmation of brain death decreases the duration of explaining brain death and potentially increases the number of organs to be donated.

In our study, CTA confirmed the diagnosis of brain death in all 20 patients with $100 \%$ sensitivity. From the point where examination results of the patient support the death, attempts are made to establish eligibility of patient-transfer-radiology. However, it was thought that scoring is affected by several factors including lack of CT device in intensive care units, prolonged durations to refer intensive care unit patients for CTA until night and even next night because of the intensity of patients with appointment. Studies have reported various advantages and disadvantages of CTA method (13). CTA has numerous advantages for the diagnosis of cerebral circulation arrest: it is a less invasive method available in many centers, requires less operator dependency, provides results rapidly and enables evaluation of patients in the presence of central nervous system (CNS) depressants. Marchand et al. reported that CTA is less invasive and more accessible than DSA, which is used as the gold standard in the diagnosis of brain death, takes shorter time to perform compared to MRA or cerebral blood flow scintigraphy, and is less operator-dependent compared to transcranial doppler method (19). In addition, is the only test enabling simultaneous screening of the body before organ transplantation. On the other hand, evaluation of CTA results is not easy. In addition, delayed Phase- 2 imaging performed after the first images acquired without contrast agent lead to "slow diffusion of contrasty agent" event, which may cause false-positive results (19).

The results of our study are largely consistent with many previous studies. Although studies have generally reported high sensitivity rates, the effectiveness and reliability of this method remain controversial in the literature because of the lack of sufficient studies on the specificity of this method. Further prospective studies especially including a control group consisting of comatose patients for comparison are needed to determine the specificity of this method.

This study has several limitations. Its retrospective and single center design, and relatively small number of patients may be considered as the limitations. However, the results of our study would contribute to 
establish reporting standards in patients whom death report is requested, and would be guiding in future studies to be conducted on this issue.

In conclusion, computed tomography angiography (CTA) has advantages in the confirmation of the diagnosis of brain death, including being non-invasive, giving results more rapidly and wider availability. The statistical performance of CTA is compatible with many confirmatory tests. However, studies for reducing negative aspects such as the effects of contrast enhancement are ongoing. We think that 10-point scoring system used in the evaluation of CTA is sufficient in the confirmation of the diagnosis of brain death before organ transplantation. We believe that our results would provide contribution to the findings supporting the use of CTA as an effective and reliable method in the confirmation of the diagnosis of brain death.

Given the problems encountered in confirmation of brain death in our country, and especially the scarcity of published studies on the efficacy of CTA in the confirmation of brain death, we believe that our study would provide contribution to the literature.

Conflict of interest: Author declares that there is no conflict of interest between the authors of the article.

Financial conflict of interest: Author declares that he did not receive any financial support in this study.

Address correspondence to: Işıl Yurdaışık, Istinye University Gaziosmanpasa Medical Park Hospital, Department of Radiology, Istanbul, Turkey

e-mail: mdisilyurdaisik@gmail.com

Telephone: 0 (212) 9793000

\section{REFERENCES}

1. https://news.harvard.edu/gazette/story/2018/07/harvardethicist-robert-truog-on-why-brain-death-remainscontroversial/ [Access date: $27 / 10 / 2018]$

2. https://organ.saglik.gov.tr/0TR/70lstatistik/ OrganNakillstatistikKamusal.aspx [Access date: 27/10/2018]

3. Erdogan $A$. Yoğun bakım ünitelerinde beyin ölümünün teşhisi. Med J SDU 2014;21(4):158-62.

4. Eelco FMW, Panayiotis NV, Gary SG. Evidence-based guideline update: Determining brain death in adults. Neurology 2010;74(23):1911-8.
5. Shemie SD, Doig C, Dickens B, et al. Severe brain injury to neurological determination of death: Canadian forum recommendations. CMAJ 2006;174(6):S1-13.

6. Dupas B, Gayet-Delacroix M, Villers D, et al. Diagnosis of brain death using two-phase spiral CT. AJNR Am J Neuroradiol 1998;19(4):641-7.

7. Calixto M. Diagnosis of brain death. Neurology International 2010;(2):7-13.

8. Sawicki M, Bohatyrewicz R, Safranow K, et al. Computed tomographic angiography criteria in the diagnosis of brain death-comparison of sensitivity and interobserver reliability of different evaluation scales. Neuroradiology 2014;56(8):60920.

9. van der Lugt A. Imaging tests in determination of brain death. Neuroradiology 2010;52:945-7.

10. Hilal S, Yeliz P. CT angiography as a confirmatory test in diagnosis of brain death: Comparison between three scoring systems. Diagn Interv Radiol 2015;21:177-83.

11. Kayhan $K$, Seden D, Aysun $Y$ C, et al. Confirming the brain death diagnosis using brain CT angiography: Experience in Tokat State Hospital. Int J Clin Exp Med 2014;7(7):1747-51..

12. Sawicki $M$, Bohatyrewicz $R$, Safranow $K$, et al. CTA in the diagnosis of brain death. Pol J Raiol 2014;78:417-21.

13. Frampas $E$, Videcoq $M$, de Kerviler $E$, et al. CT angiography for brain death diagnosis. AJNR Am J Neuroradiol 2009;30:1566-70.

14. Garrett MP, Williamson RW, Bohl MA, et al. Computed tomography angiography as a confirmatory test for the diagnosis of brain death. J Neurosurg 2018;128(2):639-44.

15. Brasil S, Bor-Seng-Shu E, de-Lima-Oliveira M, et al. Role of computed tomography angiography and perfusion tomography in diagnosing brain death: A systematic review. J Neuroradiol 2016;43:133-40.

16. Combes JC, Chomel A, Ricolfi F, et al. Reliability of computed tomographic angiography in the diagnosis of brain death. Transplant Proc 2007;39:16-20.

17. Taylor T, Dineen RA, Gardiner DC, et al. Computed tomography (CT) angiography for confirmation of the clinical diagnosis of brain death. Cochrane Database Syst Rev. 2014; 31(3):CD009694.

18. Berenguer CM, Davis FE, Howington JU. Brain death confirmation: Comparison of computed tomographic angiography with nuclear medicine perfusion scan. J Trauma 2010;68(3):553-9.

19. Marchand AJ, Seguin P, Malledant $Y$, et al. Revised CT angiography venous score with consideration of infratentorial circulation value for diagnosing brain death. Ann Intensive Care. 2016;6(1):88. 